\title{
PENGARUH PERTUMBUHAN ASET TERHADAP PROFITABILITAS MELALUI STRUKTUR MODAL
}

\author{
Studi Kasus PT. Industri Jamu dan Farmasi Sido Muncul Tbk yang terdaftar di \\ Bursa Efek Indonesia \\ Effect of Asset Growth on Profitability \\ Through Capital Structure \\ Case Study of PT. Industri Jamu dan Farmasi Sido Muncul Tbk registered at \\ Indonesia Stock Exchange
}

\author{
Merlin Novitasari' ${ }^{1}$, Daryono Setiadi², Samsul Anwar ${ }^{3}$ \\ daryonosetiadife@unwir.ac.id; samsulanwarfe@unwir.ac.id; \\ Manajemen FE, Universitas Wiralodra
}

\begin{abstract}
Abstrak
Pertumbuhan Aset, Struktur Modal, dan Profitabilitas di PT. Industri Jamu dan Farmasi Sido Muncul Tbk yang terdaftar di Bursa Efek Indonesia. Metode yang digunakan dalam penelitian ini adalah metode Deskriptif, Asosiatif yaitu melihat dan menggambarkan keadaan secara sistematis dengan cara mengumpulkan data berdasarkan fakta - fakta yang nampak dalam laporan keuangan PT. Industri Jamu dan Farmasi Sido Muncul Tbk. Data keuangan yang diambil berupa laporan laba rugi dan neraca keuangan perusahaan selama 6 tahun dari tahun 2013 sampai dengan tahun 2019. Penelitian ini menggunakan metode Uji normalitas, analisis koefisien korelasi tunggal, dan analisis koefisien determinasi.

Berdasarkan dari analisis data pada pengaruh variabel Pertumbuhan Aset terhadap Struktur Modal. Pada Analisis Korelasi (r) diperoleh sebesar -0,19 yang berarti pengaruh antara variabel Pertumbuhan Aset terhadap Struktur Modal mempunyai tingkat pengaruh yang sangat rendah namun dengan arah yang negatif. Untuk Koefisien Determinasi Pertumbuhan Aset terhadap Struktur Modal sebesar 3,61\%. yang berarti kontribusi yang diberikan Pertumbuhan Aset terhadap Struktur Modal mencapai 3,61\% dan sisanya $96,39 \%$ dipengaruhi oleh variabel lain yang tidak diteliti.

Berdasarkan dari analisis data pada pengaruh variabel struktur modal terhadap profitabilitas. pada analisis korelasi (r) diperoleh sebesar 0,87 yang berarti pengaruh antara variabel struktur modal terhadap profitabilitas mempunyai tingkat pengaruh yang sangat kuat dengan arah yang positif. Untuk Koefisien Determinasi struktur modal terhadap profitabilitas sebesar 75,69\%. Yang berarti kontribusi yang diberikan struktur modal terhadap profitabilitas mencapai $75,69 \%$ dan sisanya $24,31 \%$ dipengaruhi oleh variabel lain yang tidak diteliti.
\end{abstract}

Kata Kunci : Pertumbuhan Aset, Struktur Modal, dan Profitabilitas

\begin{abstract}
Asset Growth, Capital Structure and Profitability Costs at PT. Industri Jamu and Farmasi Sido Muncul Tbk which are listed on the Indonesia Stock Exchange. The method used in this study is Descriptive, Associative method that is to see and describe the situation systematically by collecting data based on facts that appear in the financial statements of PT. Industri Jamu and Farmasi Sido Muncul Tbk. Financial data taken in the form of income statement and balance sheet of the company for 6 years from 2013 to 2018. This study uses normality test method, single correlation coefficient analysis, and analysis of the coefficient of determination

Based on data analysis on the influence of Asset Growth variable on Capital Structure. In the Correlation Analysis (r) is obtained at -0.19, which means the influence of the variable Asset Growth on Capital Structure has a very low level of influence but with a negative direction. For the Determination Coefficient, the Asset Growth on Capital Structure is $3.61 \%$. which means that the contribution given by Asset Growth to Capital Structure reached $3.61 \%$ and the remaining 96,39\% was influenced by other variables not examined.

Based on data analysis on the effect of Capital Structure variables on Profitability. in the correlation analysis $(r)$ is obtained at 0.87, which means that the effect between Asset Growth variables on Profitability has a very strong level of influence in a positive direction. For the Sales Determination Coefficient, the Capital Structure on Profitability of 75,69\%. Which means the contribution given by Capital Structure to Profitability reaches $75,69 \%$. and the remaining $24,31 \%$ is influenced by other variables not examined.
\end{abstract}

Keyword : Asset Growth, Capital Structure, Profitability 


\section{PENDAHULUAN}

Semakin berkembangnya dunia usaha pada saat ini menyebabkan semakin kompleks masalah yang timbul dan semakin ketat iklim persaingan yang harus dihadapi oleh sebuah perusahaan, terutama perusahaan yang bergerak di bidang makanan dan minuman. Untuk menghadapi ketatnya suatu persaingan dan meningkatkan laba di dalam sebuah perusahaan maka perusahaan tersebut harus mempunyai suatu tujuan yang jelas dan sudah ditentukan. Agar dapat mempertahankan perusahaan dalam menghadapi ketatnya persaingan yang ada. Keberhasilan perusahaan untuk mencapai tujuan yang telah ditentukan tergantung pada kemampuan manajer dalam mengelola perusahaan melalui stategi dan cara yang efektif dan efisien. Suatu tujuan perusahaan adalah meningkatkan profitabilitas. Dengan meningkatnya profitabilitas perusahaan maka perusahaan memperoleh keuntungan yang besar dengan keuntungan yang besar maka perusahaan dapat mengembangkan usahanya dan dapat membayar kewajiban-kewajibannya. Dari sekian banyak rasio profitabilitas maka peneliti meneliti menggunakan Return On Equity (ROE). Yang menunjukan bahwa Return On Equity merupakan suatu kemampuan modal untuk mengukur laba setelah pajak dengan modal sendiri yang di investasikan dalam perusahaan.

Pertumbuan aset yang dimiliki oleh perusahaan selalu meningkat, maka aset tersebut semakin besar, dengan aset yang
Merlin Novitasari, Daryono Setiadi, Samsul Anwar besar sangat memungkinkan sebuah perusahaan mengembangkan usahanya sehingga perusahaan dapat memperluas pasarnya dengan memperluas pasar maka diharapkan keuntungan bertambah sehingga perusahaan akan mampu untuk membayar kewajiban-kewajibannya, membagikan deviden kepada pemegang saham.

Besarnya aset yang dimiliki oleh perusahaan, bukan hanya hak perusahaan saja tetapi terdapat hak dari pihak lain juga karena sebagiannya berasal dari pinjaman/hutang. Kebutuhan pendanaan harus dapat terpenuhi oleh setiap perusahaan dalam jumlah yang cukup baik berasal dari modal sendiri maupun hutang. Ketika aktifitas perusahaan meningkat, ketersediaan modal yang cukup untuk membiayai kegiatan perusahaan harus dapat segera dipenuhi agar tidak terjadi hambatan. Sebaliknya ketika aktifitas perusahaan menurun akan menimbulkan jumlah kas yang terlalu besar dan terjadi kelebihan modal yang menjadi beban perusahaan. Maka manajemen harus menerapkan kebijakan struktur modal dalam pendanaannya yang efektif dan efisien.

Struktur modal (capital structur) merupakan perbandingan hutang dan modal sendiri yang mempunyai peran sangat penting dalam membiayai aktifitas operasional perusahaan. Besarnya struktur modal sangat tergantung dari komposisi sumber dana yang diperoleh baik dari pihak eksternal maupun internal perusahaan, yang berupa hutang dan modal sendiri. Sejalan dengan aktifitas sehari- 
hari, perusahaan memerlukan modal tambahan yang tidak sedikit. Adapun kekurangan dana ini dapat mengakibatkan terhentinya kegiatan perusahaan. Sehingga tambahan dana sangat diperlukan. Menurut sifatnya ada dua macam tipe pendanaan yaitu pendanaan dari luar dan pendanaan dari dalam. Pendanaan dari luar berupa pinjaman serta surat berharga yang dapat dijual melalui pasar modal. Sedangkan pendanaan dari dalam berupa laba ditahan yang berasal dari kegiatan operasional maupun kegiatan non operasional.

Dalam penetapan sumber dana manakah yang akan dipilih, perusahaan harus menganalisis agar diperoleh struktur modal yang optimal yang berarti meminimalkan resiko (biaya) dan memaksimalkan keuntungan perusahaan. Perusahaan yang memiliki struktur modal yang optimal akan menghasilkan tingkat pengembalian yang optimal pula sehingga bukan hanya perusahaan yang memperoleh keuntungan saja, tetapi para pemegang sahampun akan memperoleh keuntungan tersebut. Dalam menentukan perimbangan antara modal asing dengan modal sendiri, perusahaan harus memperhatikan faktor-faktor yang mempengaruhi struktur modal yang optimal.

\section{TINJAUAN PUSTAKA}

Profitabilitas

Dalam kegiatan usaha, tujuan memperoleh keuntungan merupakan hal yang paling penting diterapkan oleh perusahaan.
Merlin Novitasari, Daryono Setiadi, Samsul Anwar Karena dengan keuntungan yang besar perusahaan dapat membayar kewajibankewajibannya, membagikan deviden maupun mengembangkan usahanya.

Pengertian Profitabilitas

Menurut Agus Sartono (2010:122), menyatakan bahwa:

"Profitabilitas adalah kemampuan perusahaan memperoleh laba dalam hubungannya dengan penjualan, total aktiva maupun modal sendiri”.

Profitabilitas suatu perusahaan dapat dinilai melalui berbagai macam cara, tergantung pada laba dan aktiva atau modal yang akan diperbandingkan antara satu dengan yang lainnya. Dalam penelitian ini peneliti menggunakan rasio Return On Equity (ROE) untuk menghitung rasio profitabilitas.

Berikut definisi Return On Equity (ROE) menurut para ahli:

Menurut Kasmir (2016:204), menyatakan bahwa:

"Return On equity atau rentabilitas modal sendiri merupakan rasio untuk mengukur laba bersih sesudah pajak dengan modal sendiri”.

Menurut Lukman Syamsuddin (2011:64), menyatakan bahwa:

"Return On equity merupakan suatu pengukuran dari penghasilan (income) yang tersedia bagi para pemilik perusahaan (baik pemegang saham biasa maupun pemegang Return On equity merupakan suatu pengukuran dari penghasilan. (income) yang saham prefern) atas modal yang mereka investasikan di dalam perusahaan”. 
Berdasarkan dua pendapat para ahli di atas return on equity adalah suatu kemampuan modal untuk mengukur laba setelah pajak dengan modal sendiri yang di investasikan dalam perusahaan.

Indikator Return On Equity

Dalam penelitian ini, indikator return on equity yang diteliti diambil dari pendapat Kasmir (2016:204), adalah:

1. Laba Setelah Pajak

2. Modal Sendiri

Faktor-Faktor yang Mempengaruhi Return On Equity

Menurut Eduartdus Tandelilin (2010:373), adapun faktor-faktor yang mempengaruhi return on equity dipengaruhi oleh 3 (tiga) faktor yaitu:

1) Margin Laba Bersih/Profit Margin

2) Perputaran Total Aktiva/ Turn Over dari Operating Assets

3) Rasio Hutang/Debt Ratio

Pertumbuhan Aset

Pertumbuhan aset adalah perubahan peningkatan atau penurunan total aset yang dimiliki oleh perusahaan. Aset mempunyai manfaat ekonomi di masa mendatang. Besarnya aset yang dimiliki sangat memungkinkan sebuah perusahaan untuk mengembangkan usahanya atau digunakan untuk mencicil hutang.

Pengertian Pertumbuhan Aset

Menurut Suad Husnan (2012: 9), menyatakan bahwa:
Merlin Novitasari, Daryono Setiadi, Samsul Anwar "Aset adalah manfaat ekonomi yang mungkin terjadi dimasa mendatang yang diperoleh atau dikendalikan oleh suatu entitas tertentu sebagai akibat transaksi atau peristiwa masa lalu”.

Menurut Aries Heru Prasetyo (2011:110), menyatakan bahwa:

\section{"Pertumbuhan Aset merupakan pertumbuhan} perusahaan selalu identik dengan aset perusahaan baik aset fisik seperti tanah, bangunan, gedung serta aset keuangan seperti kas, piutang dan lain sebagiannya”.

Indikator Pertumbuhan Aset

Dalam penelitian ini, indikator pertumbuhan aset yang diteliti diambil dari pendapat Bhaduri dalam Ervina (2010), adalah:

1. Persentase perubahan total aset tahun tertentu

2. Persentase perubahan total aset tahun sebelumnya

Faktor-Faktor yang Mempengaruhi Pertumbuhan Aset

Menurut Kasmir (2008 : 89), faktorfaktor yang mempengaruhi pertumbuhan aset antara lain adalah:

1) Pertumbuhan dana pihak ketiga (DPK)

2) Pertumbuhan kredit (pembiayaan)

3) Resiko kredit

4) Likuiditas

Karakteristik Aset

Aset harus memiliki manfaat ekonomi untuk masa depan, yang kemungkinan diperoleh atau dikendalikan oleh entitas 
tertentu sebagai hasil dari transaksi atau kejadiaan pada masa lalu, di bawah ini dijelaskan mengenai karakteristik aset:

Menurut IAI (2007:11), menyatakan bahwa aset memiliki tiga karakteristik utama yaitu:

1) Memiliki manfaat ekonomi dimasa mendatang

Praktiknya manfaat ekonomi tersebut dapat mengalir keperusahaan dengan berbagai cara seperti:

a) Baik digunakan sendiri atau bersama aset lain dalam produksi barang dan jasa yang dijual oleh unit usaha.

b) Dapat dipertukarkan dengan aset lain.

c) Dapat digunakan untuk melunasi hutang

d) Dapat dibagi kepada pemilik perusahaan

2) Diperoleh dan diakui oleh unit usaha

3) Hasil transaksi masa lalu

\section{Konsep Penilaian Aset}

Penilaian aset menurut Bambang Sujono (2011:78), adalah proses penentuan jumlah rupiah untuk menentukan makna ekonomi dari suatu aset yang akan disajikan dalam neraca. Konsep penilaian berkaitan dengan masalah penentuan makna yang ingin disampaikan pada pemakai laporan terhadap aset yang bersangkutan.

1) Tujuan Penilaian

Tujuan pengukuran/penilaian aset adalah sebagai berikut:
Merlin Novitasari, Daryono Setiadi, Samsul Anwar

a) Sebagai salah satu langkah dalam pengukuran laba.

b) Sebagai salah satu langkah dalam proses penyajian posisi keuangan.

c) Memenuhi kebutuhan informasi yang ingin dicapai dalam pelaporan keuangan.

d) Memenuhi kebutuhan informasi khusus yang memerlukan penilaian untuk kepentingan manajemen.

2) Dasar Penilaian

Hendriksen dan Van Breda (1992) menyebutkan bahwa ada dua jenis nilai pertukaran yang dapat digunakan yaitu nilai keluaran (output value) dan nilai masukan (input value).

\section{Struktur Modal}

Kebutuhan dana perusahaan dapat disediakan melalui sumber intern (modal sendiri) maupun sumber ekstern (modal luar). Pemenuhan pendanaan perusahaan merupakan hal yang penting untuk memperkuat posisi keuangan perusahaan terutama saat menghadapi kesulitan keuangan di masa mendatang.

Pengertian Struktur Modal

Menurut Irham Fahmi (2011:106), menyatakan bahwa:

"Struktur modal merupakan gambaran dari bentuk proporsi finansial perusahaan yaitu antara modal yang dimiliki yang bersumber dari hutang jangka panjang dan modal sendiri yang menjadi sumber pembiayaan suatu perusahaan”. 
Menurut Bambang Riyanto (2010:216), menyatakan bahwa:

"Struktur modal dapat diartikan sebagai perimbangan atau perbandingan antara jumlah hutang jangka panjang dengan modal sendiri. Dalam neraca perusahaan yang terdiri dari sisi aktiva yang mencerminkan struktur kekayaan dan sisi pasiva sebagai struktur keuangan. Struktur modal sendiri merupakan bagian dari struktur keuangan yang dapat diartikan sebagai pembelanjaan permanen yang mencerminkan perimbangan antara hutang jangka panjang dengan modal sendiri".

Menurut Bambang Riyanto (2010:261), indikator struktur modal antara lain:

1. Hutang jangka panjang

2. Modal sendiri

Faktor-Faktor yang Mempengaruhi Struktur Modal

Menurut Musthafa (2017:87), faktorfaktor yang mempengaruhi struktur modal adalah:

1) Growth Rate, Pertumbuhan Penjualan Masa Depan

2) Sales Stability, Stabilitas Penjualan

3) Asset Structur, Structur Aktiva

4) Management Attitudes, Sifat Manajemen

5) Market Conditions, Keadaan Pasar Modal

6) Taxes, Pajak

Bentuk-Bentuk Modal
Merlin Novitasari, Daryono Setiadi, Samsul Anwar

Menurut Suad Husnan (2012:299), menyatan bahwa semua "Struktur modal adalah baik, tetapi kalau mengubah struktur modal ternyata nilai perusahaan berubah, maka akan diperoleh struktur modal yang terbaik”.

Sedangkan menurut Bambang Riyanto (2010:226), menyatakan bahwa "Dengan mendasar pada konsep biaya modal, maka struktur modal yang optimum adalah struktur modal yang dapat meminimumkan biaya penggunaan modal rata-rata (avarage cost of capital)”.

Dari beberapa pengertian di atas dapat dirangkum bahwa struktur modal yang optimal adalah memaksimumkan kemakmuran para pemilik, pemegang untuk memaksimumkan nilai perusahaan atau harga saham perusahaan dan sekaligus meminimumkan biaya modal rata-rata.

Tujuan perusahaan dalam menentukan struktur modal yang optimal meminimumkan biaya modal rata-rata yang pada akhirnya untuk memperoleh dan meningkatkan penghasilan para pemegang saham. Meskipun demikian, setiap teori struktur modal memiliki kelebihan dan kekurangan yang menarik untuk dilakukan penelitian lebih lanjut.

\section{Kerangka Berfikir}

Tujuan utama didirikan perusahaan adalah untuk menghasilkan laba. Untuk menilai laba yang dihasilkan yaitu dengan menggunakan analisis profitabilitas, dari sekian banyak rasio profitabilitas satu 
diantaranya yaitu diukur dengan menggunakan return on equity (ROE).

Menurut Kasmir (2016:204), menyatakan bahwa:

"Return On Equity atau rentabilitas modal sendiri merupakan rasio untuk mengukur laba bersih sesudah pajak dengan modal sendiri”.

ROE merupakan perbandingan antara laba bersih setelah pajak dengan modal sendiri. Laba dipengaruhi juga oleh pertumbuhan aset, ketika aset meningkat laba juga akan meningkat akan tetapi jika pertumbuhan aset menurun akan berpengaruh teradap keuntungan yang akan diterima. Hal yang sama juga dialami pada kondisi struktur modal jika dana perusahaan dapat dipenuhi baik dari modal sendiri maupun modal asing (hutang) maka akan meningkat kan keuntungan. Namun apa bila keputusan pendanaan tidak cermat akan menyebabkan permasalahan pada keuntungan.

Menurut Bhaduri dalam Ervina (2010), menyatakan bahwa:

"Pertumbuhan aset adalah perubahan (peningkatan atau penurunan) total aset yang dimiliki oleh perusahaan. Pertumbuhan aset dihitung sebagai persentase perubahan aset pada tahun tertentu dengan tahun sebelumnya".

Dengan pertumbuhan aset yang meningkat maka aset yang dimiliki perusahaan semakin besar, besarnya aset yang dimiliki sangat memungkinkan sebuah perusahaan mengembangkan usahanya. Sehingga perusahaan dapat memperluas
Merlin Novitasari, Daryono Setiadi, Samsul Anwar pasarnya dengan memperluas pasar maka diharapkan keuntungan bertambah sehingga perusahaan akan mampu memenuhi kewajiban-kewajibannya. Namun perusahaan yang hanya mengejar aset besar tanpa memperhatikan sumber/asal dari mana peningkatan aset itu terjadi akan sangat beresiko bagi eksistensi perusahaan, misalnya aset yang dimiliki oleh perusahaan sebagian besar berasal dari modal asing (hutang), sehingga akan sangat beresiko bagi perusahaan bila tidak mampu untuk melunasi dan berakhir dengan kebangkrutan. Begitu pula dalam kegiatan operasionalnya perusahaan harus mampu mengelola sumbersumber pendanaan dengan memperhatikan struktur modal sesuai dengan kebutuhan perusahaan maka perusahaan harus melakukan perimbangan terhadap hutang dan modal sendiri yang akan digunakan.

Menurut Bambang Riyanto (2010:216), menyatakan bahwa:

"Struktur modal dapat diartikan sebagai perimbangan atau perbandingan antara jumlah hutang jangka panjang dengan modal sendiri. Dalam neraca perusahaan yang terdiri dari sisi aktiva yang mencerminkan struktur kekayaan dan sisi pasiva sebagai struktur keuangan. Struktur modal sendiri merupakan bagian dari struktur keuangan yang dapat diartikan sebagai pembelanjaan permanen yang mencerminkan perimbangan antara hutang jangka panjang dengan modal sendiri”. 
Struktur modal (capital structur) merupakan perbandingan hutang dan modal sendiri yang mempunyai peran yang sangat penting dalam membiayai aktifitas oprasional perusahaan. Dalam penerapan kebijakan struktur modal, perusahaan harus didasarkan pada kemampuan keuangan yang dimiliki, jangan sampai sumber pendanaan ekstern digunakan untuk membiayai kegiatan operasional perusahaan menjadi lebih besar, sementara sumber-sumber pendanaan perusahaan lebih kecil, sehingga mengakibatkan perusahaan menjadi lebih rugi. Sebuah perusahaan dalam pemenuhan kebutuhannya harus mengutamakan sumber intern perusahaan, sehingga akan mengurangi ketergantungan terhadap pihak luar. Untuk itu struktur modal yang optimum dimana jumlah hutang tidak lebih besar dari modal sendiri yang dimemiliki perusahaan, agar meminimumkan biaya penggunaan modal sehingga mampu memberikan profitabilitas yang maksimal.

Berdasarkan pemikiran tersebut dapat dirangkum bahwa semakin meningkatnya pertumbuhan aset maka semakin besar aset yang diperuntukan untuk mengembangkan usaha, melalui kebijakan struktur modal yang diterapkan akan menentukan besar kecilnya kemampuan perusahaan memperoleh keuntungan. Jika perusahaan menggunakan modal asing (hutang) untuk mengembangkan usahanya maka keuntungan yang diperoleh dapat digunakan untuk mencicil hutang.
Merlin Novitasari, Daryono Setiadi, Samsul Anwar Hipotesis Penelitian

Dengan berdasar pada teori yang relevan dan belum didasarkan pada fakta-fakta yang diperoleh melalui pengumpulan data. Dari kerangka berfikir yang telah diuraikan, maka peneliti memperoleh hipotesis sebagai berikut:

\begin{tabular}{|c|c|c|c|c|}
\hline \multirow{2}{*}{$\begin{array}{l}\text { Pertumbuhan } \Lambda \text { set } \\
\qquad\left(\mathrm{X}_{1}\right)\end{array}$} & $H_{I}$ & \multirow{2}{*}{$\begin{array}{l}\text { Struktur Modal } \\
\qquad\left(\mathrm{X}_{2}\right)\end{array}$} & $\mathrm{H}_{2}$ & Profitabilitas \\
\hline & & & & $(\mathrm{Y})$ \\
\hline
\end{tabular}

\section{Hipotesis Penelitian}

$\mathrm{H}_{1}$ : Diduga pertumbuhan aset berpengaruh terhadap struktur modal

$\mathrm{H}_{2}$ : Diduga struktur modal berpengaruh terhadap profitabilitas

\section{METODE PENELITIAN}

Dalam melakukan penelitian ini peneliti menggunakan metode deskriptif dan asosiatif dengan menggunakan data kuantitatif.

Metode deskriptif dalam penelitian ini digunakan untuk mengetahui gambaran mengenai masing-masing variabel yaitu pertumbuhan aset, struktur modal dan profitabilitas PT. Industri Jamu dan Farmasi Sido Muncul Tbk yang terdaftar di Bursa Efek Indonesia dan metode asosiatif dalam penelitian ini digunakan untuk mengetahui pengaruh Pertumbuhan Aset terhadap Profitabilitas melalui Struktur Modal pada PT. Industri Jamu dan Farmasi Sido Muncul Tbk yang terdaftar di Bursa Efek Indonesia. Data keuangan yang diambil berupa laporan laba rugi dan neraca keuangan perusahaan selama enam tahun dari tahun 2013 sampai dengan tahun 2018. Penelitian 
ini menggunakan metode, analisis koefisien korelasi tunggal, dan analisis koefisien determinasi.

\section{PEMBAHASAN}

Analisis Deskriptif

Mean Profitabilitas, Pertumbuhan Aset dan Struktur Modal

Pada PT. Industri Jamu Dan Farmasi Sido Muncul Tbk

Tahun 2013-2018

\begin{tabular}{|c|c|c|c|}
\hline Tahun & Profitabilitas & $\begin{array}{c}\text { Pertumbuhan } \\
\text { Aset }\end{array}$ & $\begin{array}{c}\text { Struktur } \\
\text { Modal }\end{array}$ \\
\hline 2013 & 15,47 & 37,39 & 0,66 \\
\hline 2014 & 15,85 & $-4,58$ & 0,52 \\
\hline 2015 & 16,85 & $-0,86$ & 0,53 \\
\hline 2016 & 17,43 & 6,85 & 0,51 \\
\hline 2017 & 18,44 & 5,71 & 1,86 \\
\hline 2018 & 22,88 & 5,69 & 2,29 \\
\hline Jumlah & 106,91 & 61,08 & 6,37 \\
\hline$N=6$ & $\mathrm{Me}=17,82$ & $M e=10,18$ & $\begin{array}{c}\mathrm{Me}= \\
\left(\sum \mathrm{x} 1\right) / \mathrm{n}\end{array}$ \\
\hline
\end{tabular}

Sumber : Data sekunder yang telah diolah

Uji Normalitas

Untuk menguji kenormalan distribusi sampel yang dilakukan pada penelitian ini agar dapat dipertanggung jawabkan dan digunakan analisis yang tepat, maka dilakukan uji normalitas terhadap data sampel yang diperoleh dari Laporan Keuangan PT. Industri Jamu Dan Farmasi Sido Muncul Tbk diuji dengan Metode Chi Kuadrat $\left(\mathrm{X}^{2}\right)$ menurut Sugiyono (2017 : 107) rumus Chi Kuadrat adalah sebagai berikut :

$$
X^{2}=\frac{\sum(f 0-f h)^{2}}{f h}
$$

Dimana :

$\mathrm{X}^{2}=$ Chi Kuadrat
Merlin Novitasari, Daryono Setiadi, Samsul Anwar $\mathrm{f}_{\mathrm{o}}=$ Frekuensi hasil diobservasi dari sampel penelitian

$\mathrm{f}_{\mathrm{h}}=$ frekuensi yang diharapkan pada populasi penelitian

Bila harga Chi Kuadrat hitung lebih kecil atau sama dengan Chi Kuadrat tabel $\left(\mathrm{X}_{\mathrm{h}}{ }_{\mathrm{h}} \leq \mathrm{X}^{2}{ }_{1}\right)$ maka data sampel berdistribusi tidak normal.

Normalitas Profitabilitas

$$
\mathrm{X}^{2} \text { hitung }=\sum \frac{(f o-f h)}{f h}=\mathbf{9 , 8 2 9}
$$

Normalitas Pertumbuan Aset

$$
\mathrm{X}^{2} \text { hitung }=\sum \frac{(f o-f h)}{f h}=\mathbf{9 , 8 2 9}
$$

Normalitas Struktur Modal

$$
\mathrm{X}^{2} \text { hitung }=\sum \frac{(f o-f h)}{f h}=\mathbf{9 , 8 2 9}
$$

Chi Kuadrat $\mathrm{X}^{2}$ hitung $\leq 11,070$ maka termasuk pada distribusi normal.

Metode Assosiatif

Analisis Korelasi Tunggal

Korelasi $\mathbf{X}_{\mathbf{1}}$ (Pertumbuhan Aset) terhadap $\mathbf{X}_{\mathbf{2}}$ (Struktur Modal)

Berdasarkan perhitungan pada tabel diatas maka koefisien korelasi tunggal (r) dapat dihitung sebagai berikut :

$$
\begin{aligned}
& r x_{1} x_{2}=\frac{n \sum x 1 x 2-\left(\sum x 1\right)\left(\sum x 2\right)}{\sqrt{\left(n \sum x 1^{2}-\left(\sum x 1\right)^{2}\left(n \sum x 2^{2}-\left(\sum x 2\right)^{2}\right)\right.}} \\
& r x_{1} x_{2}= \\
& \frac{6(54,64)-(61,08)(6,37)}{\sqrt{\left(6(1531,6)-(61,08)^{2}\right)\left(6(9,93)-(6,37)^{2}\right)}} \\
& r x_{1} x_{2}=\frac{-61,23}{322,13}=\mathbf{- 0 , 1 9}
\end{aligned}
$$

Berdasarkan perhitungan di atas diperoleh hasil korelasi antara Pertumbuan Aset terhadap Struktur Modal sebesar -0,19 yang berarti bahwa pengaruh Pertumbuan Aset terhadap Struktur Modal 
adalah Sangat Rendah dengan arah hubungan yang Negatif.

Korelasi $\mathbf{X}_{2}$ (Struktur Modal) terhadap Y

(Profitabilitas)

Berdasarkan perhitungan maka koefisien korelasi tunggal (r) dapat dihitung sebagai berikut:

$\mathrm{rx}_{2} \mathrm{Y}=\frac{n \sum x 2 Y-\left(\sum x 2\right)\left(\sum Y\right)}{\sqrt{\left(n \sum x 2^{2}-\left(\sum x 2\right)^{2}\right)\left(n \sum Y^{2}-\left(\sum Y\right)^{2}\right)}}$

$r x_{2} Y=$

$\frac{6(122.93)-(6,37)(106,91)}{\sqrt{\left(6(9,93)-(6,37)^{2}\right)\left(6(1941,44)(106,91)^{2}\right)}}$

$r x_{1} x_{2}=\frac{56,5633}{64,4962}=0,87$

Dari perhitungan korelasi diatas maka diperoleh hasil koefisien korelasi antara Struktur Modal terhadap Profitabilitas sebesar 0,87 yang berarti bahwa pengaruh Struktur Modal terhadap Profitabilitas mempunyai hubungan yang sangat kuat dan mempunyai arah positif.

Analisis Koefesien Determinasi

Koefisien determinasi merupakan suatu ukuran yang menunjukkan besar sumbangan dari variabel penjelas terhadap variabel respon. Dengan kata lain, koefisien determinasi menunjukkan ragam (variasi) naik turunnya $\mathrm{Y}$ yang diterangkan oleh pengaruh linier $\mathrm{X}$. Koefisien determinasi (Koefisien penentu) dinyatakan dengan rumus:

$$
\mathrm{Kd}=\mathrm{r}^{2} \times 100 \%
$$

Dimana :

$\mathrm{Kd}=$ Koefisien determinasi

$\mathrm{r}=$ Koefisien korelasi
Merlin Novitasari, Daryono Setiadi, Samsul Anwar Analisis Koefesien Determinasi Pertumbuhan Aset Terhadap Struktur Modal

Untuk mengetahui besarnya pertumbuan aset terhadap struktur modal, maka digunakan rumus Koefisien Determinasi sebagai berikut :

$K d=\mathrm{r}^{2} \times 100 \%$

$K d=-0,19^{2} \times 100 \%$

$K d=3,61 \%$

Dari hasil perhitungan diatas diperoleh koefisien determinasi sebesar $3,61 \%$. Konstribusi yang diberikan pertumbuhan aset terhadap struktur modal yaitu sebesar 3,61\% dan sisanya 96,39\% dipengaruhi oleh variabel lain yang tidak diteliti.

Analisis Kofesien Determinasi Struktur Modal Terhadap Profitabilitas

Untuk mengetahui besarnya konstribusi Penjualan terhadap Return on investment, maka digunakan rumus Koefisien Determinasi sebagai berikut:

$K d=\mathrm{r}^{2} \times 100 \%$

$K d=0,87^{2} \times 100 \%$

$K d=75,69 \%$

Dari hasil perhitungan diatas diperoleh koefisien determinasi sebesar 75,69\%. Konstribusi yang diberikan struktur modal terhadap profitabilitas yaitu sebesar $75,69 \%$ dan sisanya $24,31 \%$ dipengaruhi oleh variabel lain yang tidak diteliti.

\section{KESIMPULAN}

Berdasrkan hasil pengujian dari pembahasan tentang Pengaruh Pertumbuhan Aset Terhadap Profitabilitas Melalui Struktur 
Modal pada PT. Industri Jamu dan Farmasi Sido Muncul Tbk yang terdaftar di Bursa Efek Indonesia tahun 2013-2018 maka diperoleh kesimpulan sebagai berikut:

1. Berdasarkan perhitungan analisis korelasi tunggal, diperoleh hasil korelasi antara Perumbhan Aset terhadap Struktur Modal sebesar -0,19 yang berarti bahwa pengaruh Perumbhan Aset terhadap Struktur Modal adalah sangat rendah dengan arah hubungan yang negatif. Koefisien determinasi $\mathrm{Kd}=3,61 \%$ artinya bahwa variabel pertumbuhan aset memberikan kontribusi terhadap struktur modal sebesar $3,61 \%$ sedangkan sisanya 96,39\% dipengaruhi oleh variabel lain yang tidak diteliti oleh peneliti.

2. Berdasarkan perhitungan analisis korelasi tunggal, diperoleh hasil korelasi antara Struktur Modal terhadap Profitabilitas sebesar 0,87 yang berarti bahwa pengaruh Struktur Modal terhadap Profitabilitas adalah sangat kuat dengan arah hubungan yang positif. Koefisien determinasi $\mathrm{Kd}=$ $75,69 \%$ artinya bahwa variabel Struktur Modal memberikan kontribusi terhadap Profitabilitas sebesar $75,69 \%$ sedangkan sisanya $24,31 \%$ dipengaruhi oleh variabel yang tidak diteliti oleh peneliti.
Merlin Novitasari, Daryono Setiadi, Samsul Anwar

\section{DAFTAR PUSTAKA}

Brigham, Eugene F. dan Houston, Joel F. 2011. Dasar-Dasar Manajemen Keuangan Terjemahan. Edisi 10. Jakarta: Salemba Empat.

Irham Fahmi. 2011. Analisis Laporan Keuangan. Bandung: Alfabeta.

Harahap, Sofyan Syafri. 2010. Analisi Kritis Atas Laporan Keuangan. Jakarta: Rajawali Persada.

Suad Husnan. 2012. Dasar-Dasar Manajemen Keuangan. UPPAMP YKPN. Yogyakarta.

Ikatan Akuntan Indonesia. 2007. Standar Akuntansi Keuangan. Jakarta: Salemba Empat.

Jakarta: Raja Grafindo Persada.

Kasmir. 2016. Analisis Laporan Keuangan. Jakarta: Raja Grafindo Persada.

Martono, Harjito. 2013. Manajemen Keuangan (Edisi 3). Ekonisia: Yogyakarta.

Musthafa. 2017. Manajemen Keuangan. Yogyakarta: ANDI.

Prasetyo, Aries Heru. 2011. Valuasi Perusahaan. Jakarta Pusat. PPM.

Bambang Riyanto. 2016. Dasar-Dasar Pembelanjaan Perusahaan BPFE UGM, Yogyakarta.

Sartono, Agus. 2010. Manajemen Keuangan Teori dan Aplikasi Edisi Keempat. BPPE, Yogyakarta.

Sugiyono. 2016. Metode Penelitian Kuantitatif, Kualitatif, dan $R \& D$. Bandung: Penerbit Alfabeta. 
Syamsuddin, Lukman. 2011. Manajemen Keuangan Perusahaan. Jakarta: PT Grafindo Pustaka Utama.

Tandelilin, Eduartdus. 2010. Portofolio dan Investasi Teori dan Aplikasi. Edisi Pertama. Yogyakarta: Kanisius.

Warsono. 2003. Manajemen Keuangan Perusahaan. Jilid 1. Malang: Bayu Media Publishing.

\section{Jurnal Penelitian :}

Eunike Gita Tangkulung, Sri Murni dan Victoria N. Untu, 2019. Pengaruh Asset

Size dan Profitabilitas Terhadap Struktur Modal (pada Perusahaan Real Estate dan Property yang Terdaftar di BEI). Jurnal EMBA Vol. 7 No. 1 ISSN 2303-1174

Ranti Agus Astuti, Prof. Dr. Kirmizi Ritonga, MBA, Ak dan Drs. Al Azhar A, MM., Ak, 2014. Pertumbuhan Aset, Profitabilitas, dan Pertumbuhan Penjualan Terhadap Struktur Modal (Pada Perusahaan Real Estate dan Properti yang Terdaftar di BEI). Jurnal JOM FEKON Vol. 1 no. 2

Resi Yanuesti Violita dan Sri Sulasmiyat, 2017. Pengaruh Struktur Modal Terhadap Profitabilitas (pada Perusahaan Food And Baverages yang Terdaftar di BEI). Jurnal Administrasi Bisnis (JAB) Vol. 51 No. 1

Belananda Dwi Arista dan Topowijono, 2017.

Pengaruh Struktur Modal Terhadap Profitabilitas (pada Perusahaan Sub Sektor Otomotif dan Komponen yang
Merlin Novitasari, Daryono Setiadi, Samsul Anwar Terdaftar di BEI). Jurnal Administrasi Bisnis (JAB) Vol. 46 No.1

Victor P. Tandi, Perengkuan Tommy dkk, 2018. Pengaruh Struktur Modal dan Pertumbuhan Aset Terhadap Profitabilitas (Studi Pada Perusahaan Otomotif Yang Terdaftar Di BEI). Jurnal EMBA Vol. 6 No. 2 ISSN 23031174

Fira Yuliana, 2014. Analisis Pengaruh Pertumbuhan Aset dan Struktur Modal Terhadap Profitabilitas (pada Perusahaan Semen yang Terdaftar di $B E I)$. Jurnal Ekonomi dan Keuangan 